\title{
History education and 'Asian' Values for an 'Asian' Democracy: the Case of Singapore
}

\section{Summary}

Where some of the papers in this volume deal with nation building in the democratising former East European states in the wider ideological context of liberal democratic thought, this paper aims to present a view of values and democracy from an alternative, 'Asian' perspective. South East Asian nations, such as Singapore, have attempted to articulate and practise forms of 'Asian' democracy as a response to, and in rejection of, Western liberal democratic models. In these countries, there is not so much a programme of reform and liberalization, as an attempt to evolve a form of democracy suited to an Asian society. To this end, efforts have been made by political leaders to articulate what 'Asian' values are, and some countries have also promoted sets of values that are considered to be congruent with their form of 'Asian' democracy.

Singapore is an example of how a government has set about developing a form of 'Asian' democracy. By examining the history texts used in Singapore schools, and comparing the different contexts in which European and 'Asian' values are embedded and used, the paper shows that there is indeed a distinctive form of values and democracy that is taught. But, while this is referred to as 'Asian', there is in fact a lacuna in terms of the wider values framework and context, and children are in effect being socialised into accepting a rather passive conception of citizenship and a notion of democracy that are arguably distinctive to Singapore. What that Asia stands for is far too diverse, and perhaps there is also, on the part of Singapore and its political leaders, an inclination to make 'Asian' values in their own image, as it were. 


\title{
History education and 'Asian' Values for an 'Asian' Democracy: the Case of Singapore Christine Han* \\ LEID, Institute of Education, UK
}

\begin{abstract}
Where some of the papers in this volume deal with nation building in the democratising former East European states in the wider ideological context of liberal democratic thought, this paper aims to present a view of democracy and democratisation from an alternative, 'Asian' perspective. South East Asian nations, such as Singapore, have attempted to articulate and practise forms of 'Asian' democracy as a response to, and in rejection of, Western liberal democratic models. In these countries, there is not so much a programme of reform and liberalization, as an attempt to evolve a form of democracy suited to an 'Asian' society. To this end, efforts have been made by political leaders to articulate what 'Asian' values are, and Singapore will be used as an example of how a government has promoted a set of values regarded to be congruent with their form of 'Asian' democracy. By examining the history texts in Singapore, and comparing the different contexts in which European and 'Asian' values are embedded and used, the paper will elucidate the ways in which the nature of 'Asian' values and democracy differ from those advocated in Europe, and the implications of this for citizenship education.
\end{abstract}

Keywords: history education; citizenship; 'Asian'values; 'Asian' democracy; textbooks; Singapore

* LEID, Institute of Education, 20 Bedford Way, London WC1H 0AL, UK. Email: c.han@ioe.ac.uk 


\section{Introduction}

Where some of the papers in this volume deal with nation building in the democratising former East European states in the wider ideological context of liberal democratic thought, this paper aims to present a view of democracy and democratisation from an alternative, Asian perspective. South East Asian nations, such as Singapore, have attempted to articulate and practise forms of 'Asian' democracy as a response to, and in rejection of, Western liberal democratic models. In these countries, there is not so much a programme of reform and liberalization, as an attempt to evolve a form of democracy suited to an Asian society. To this end, efforts have been made by political leaders to articulate what 'Asian' values are, and Singapore will be used as an example of how a government has promoted a set of values regarded to be congruent with their version of 'Asian' democracy.

Hein and Selden point out that textbooks 'provide one of the most important ways in which nation, citizenship, the idealized past, the promised future are articulated and disseminated in contemporary societies' (Hein and Seldon, 1998: 3). Indeed, many East Asian states have sought to define the parameters of national identity and sense of patriotism in their citizens through national education systems and, specifically but not exclusively, the history curriculum (see, for instance, Goh and Gopinathan, 2005: 203). In Singapore, the subjects of Civics and Moral Education, History, Social Studies (which incorporates history and geography), and the mother tongue languages have traditionally been used to promote 'Asian' values and democracy; in recent years, National Education has also been added to the curriculum. This paper aims to examine the history texts used in Singapore schools, particularly with respect to how history is interpreted to advance a notion of citizenship suited to an 'Asian' democracy. By comparing the different cultural, political and institutional contexts in which European and 'Asian' values are embedded and used, the paper will elucidate the ways in which the nature of 'Asian' values and democracy differ from those advocated in Europe, and the implications of this for citizenship education. .

\section{Singapore}

Historical and political background

Singapore is a nation of just forty-one years. Unexpectedly granted independence from the Federation of Malaysia in 1965, it needed to mould its disparate, multi-ethnic population together as a people, and foster a sense of national identity. It has sought to do this, amongst other things, by imparting a view of history, a set of shared values, and a sense of citizenship through the curriculum.

If Schumpeter's and Dahl's notions of democracy are used, Singapore is a democracy in that its government is elected periodically in what are generally considered free elections in which citizens are able to stand as candidates, and in that there is general adult suffrage. However, critics point out that some practices are questionable in democratic terms: e.g. the practice of grouping up to six constituencies and Members of Parliament (MPs) so that, when residents in these 'Group Representation Constituencies' vote, their vote goes not to an individual MP in a single constituency, but counts as a vote for the whole team of MPs; the fact that, with the introduction these teams of MPs, so few constituencies are contested that approximately half of those eligible to vote were unable to do so in the last General Election; and the giving of priority for upgrading of housing estates to constituencies that bring in the ruling PAP (People's Action Party) candidates when public funds are used for these projects.

Citizenship education 
In this paper, citizenship education is taken to refer to the acquisition of knowledge and development of skills needed for individuals to function as citizens. Citizenship education has taken various forms in Singapore since its independence, starting with Ethics (subsequently renamed Civics), followed by Education for Living, Being and Becoming, Good Citizens, and ending with Civics and Moral Education, which is still in use today. These have been described and analysed by, among others, Chew (1998), Han (1997, 2000), Tan (1994), Tan and Chew (2004), Wang et al (2006). As the titles of the programmes suggest, citizenship education is usually combined with values education. There was also an attempt to teach religious knowledge as part of the moral and citizenship education effort, but this was abandoned after it proved to be socially divisive (Tan, 1997). In 1997, National Education (NE) was added to the curriculum to strengthen the messages of moral and citizenship education, particularly those to do with young Singaporeans' attitudes to the country (see Han, 2000; Kho, 2005). National Education takes the form of school activities distributed throughout the school year. Its messages are also incorporated in school subjects wherever appropriate, and comprise the following:

Singapore is our homeland; this is where we belong.

We must preserve racial and religious harmony.

We must uphold meritocracy and incorruptibility.

No one owes Singapore a living.

We must ourselves defend Singapore.

We have confidence in our future.

(MOE, 2004a)

The approach to moral and citizenship education is comprehensive in nature. In addition to Civics and Moral Education, and the activities associated with National Education, the desirable values and messages are also infused in and delivered through other subjects, including the History, Social Studies, and the mother tongue languages. Goh and Gopinathan note with regard to Social Studies that the syllabus was 'designed to instil a sense of national identity and its content revolves around the six key National Education messages'(Goh and Gopinathan, 2005: 214), while Sim and Print observe:

Social studies was conceived as a major vehicle for NE at the secondary school level, with a focus on the nation, common culture and shared values. Consequently it seeks to develop in students what the government deems to be the essential areas of knowledge, skills and values of an informed, responsible and participative Singapore citizen (Sim and Print, 2005a: 9).

As was seen earlier, much has been written about the various versions of moral and citizenship education programmes. In addition, Han and Tan (2007) have done work on the 'Asian' values promoted in the Chinese language texts, and Goh and Gopinathan, as well as Sim, Adler and Print have also carried out analysis of the Social Studies texts (Goh and Gopinathan, 2005; Adler and Sim, 2005; Sim and Print, 2005a).

Where 'Asian' values are concerned, Adler and Sim note that there is an element of such values in the National Education component, specifically in the 'value of communitarianism' promoted in the Social Studies texts (Adler and Sim, 2005: 3). The aim of the current paper goes beyond this to look at history texts (incorporating both the subjects of History and Social Science) with the view to explicating the way in which a particular interpretation of history is promoted and, with it, the accompanying version of 'Asian' values and democracy. Also, by examining how the texts contribute to citizenship education for an 'Asian' democracy, and the wider context in which this occurs, the paper aims to demonstrate how the approach to citizenship education differs from those found in liberal Western democracies.

\section{The 'Asian' values debate}


The term “Asian' values" was first used in the 1970s by academics attempting to explain the seemingly miraculous economic growth of the East Asian states of Japan, Singapore, South Korea, Taiwan and Hong Kong by referring to the cultural values found in those societies (see Hill, 2000; Xu, 2005; Khoo, 1999). The term was adopted in the 1990s by political leaders in South East Asia, including the former Prime Ministers of Singapore and Malaysia, Lee Kuan Yew and Mahathir Mohammad, to articulate forms of values and democracy as a challenge to Western ideology.

As characterized by the political elite in Asia, 'Asian' values were values that were 'underpinned by moral values, social norms and cultural attitudes which were said to be derived from Asian philosophical traditions and historical experiences', ranging from Confucianism to Islam (see Khoo, 1999). Lee Kuan Yew - who also used the term 'Confucian values' - spoke in terms of 'hard work, strong family ties, sacrifice for the future' as well as 'respect for education, learning, and entrepreneurial spirit, filial piety, respect for elders... and freedom in an orderly society' $(\mathrm{Xu}, 2005)$. Lee believed in strong government, and held that this was necessary for economic growth, as well as to maintain social harmony and stability in multi-ethnic and multireligious societies (Xu, 2005; Zakaria, 1994). He also believed that Asian societies were seeking a system of government that would be 'comfortable' (for them), one that would meet their needs (Zakaria, 1994).

In the case of the democratising former East European communist states, nation building takes place against the wider ideological context of liberal democratic thought. Although the cultures of Europe are diverse, the European Union (EU), the Council of Europe, and their institutions nonetheless represent a unifying force, embodying and expressing as these do a commitment to a set of liberal values. For instance, the EU web site states that there are shared values such as democracy, freedom and social justice, and that the EU defends these values (EU, n.d.). In addition, there are conventions such as that on human rights, and institutions like the European Court of Human Rights, that give substance to these values and rights. For European countries, therefore, the institutional context contributes meaning and substance to the values that are espoused.

Singapore's growth as a nation state takes place against the diverse political, social and cultural backdrop of Asia, and the values that are deemed appropriate are accordingly 'Asian' in nature. Like the countries within the EU, Singapore too is a member of the regional grouping, the Association of Southeast Asian Nations (ASEAN). The association's web site describes the grouping as existing for political, economic and functional co-operation, and gives its fundamental principles as including the right of each state to be free from external interference (ASEAN, n.d.) When placed against the EU's declared aims and values, however, there is a conspicuous lack of declared commitment to a set of shared values, such as the rights of individuals. Indeed, when a number of Asian countries reached a consensus on human rights at the World Conference on Human Rights in 1993, it was to make a case to contextualise or limit these (see World Conference on Human Rights, the Bangkok Declaration, 1993, Article 8).

The Asian financial crisis in the 1990s gave critics the opportunity to question the claim that 'Asian' values were responsible for the earlier economic miracle. But, apart from the economic arguments, the criticisms that have been made against 'Asian' values and democracy can be broadly divided into two groups. One group points out problems with the way 'Asian' values are characterized, as these are often set in opposition to 'Western' values and, as Ho points out, there is nothing unique about the values that have been described as 'Asian'; another problem is that there is no consensus on what these values are, with different groups assigning different meanings to them (Manan, 1999). The second group of criticisms takes the position that 'Asian' values are often used by governments to support or veil their authoritarian rule (Xu, 2005; Manan, 1999; see also Khoo, 1999).

In the 1990s, a number of academics attempted to make sense of the notion of 'Asian' values. Montgomery (1997) looked at the signatories to the major human rights agreements (viz. the Universal Declaration of Human Rights, the International Convention on Economic, Social and Cultural Rights, the International Convention on Civil and Political Rights, and the Vienna Declaration of 1993). Noting that only thirty-five 
Asian governments had participated in these, and that there was 'a greater disparity' of response among them than there was in other regions, he allowed that the values in these countries, while not being unique, were different, and would favour loyalties to the family and the community more than respect for individual claims. Glazer also noted that differences in values and priorities were often distinctive in that these seemed 'to aggregate into complexes characterizing a nation, a society, a culture'; he thought that there were contrasts in the values on the Western Rim of the Pacific and those on the Eastern Rim, with informed residents like journalists and academics believing, for instance, that the former tend to be more individualistic and the latter more collective in nature (see Glazer, 1997: 53).

More recently, Bell - while holding that there are no distinctly 'Asian' values - similarly allows that

It is possible that most politically relevant actors, both officials and intellectuals, in East

Asian societies typically endorse a somewhat different set of fundamental human goods

than their counterparts in Western societies now and for the foreseeable future.

(Bell, 2006: 51, 73)

Indeed, in one of the more considered characterisations of 'Asian' values, Singapore's former permanent representative to the United Nations, Bilahari Kausikan, takes a position close to this. He points out that notwithstanding the issues concerning superiority or distinctiveness - the 'Asian' values debate is 'basically about Asian societies' future direction and development' (cited in $\mathrm{Xu}, 2005$ : 24)

If the values that are emphasised in Asian societies are different from those in the liberal West, it would stand to reason that the forms democracy take in those societies would differ accordingly. Bell therefore argues that:

There are morally legitimate alternatives to Western-style liberal democracy in the East

Asian region. What is right for East Asians does not simply involve implementing

Western-style political practices when the opportunity presents itself; it involves

drawing upon East Asian political realities and cultural traditions that are defensible to

contemporary East Asians (Bell, 2006: 8).

Chan takes an empirical approach in to making a case for an 'Asian' form of democracy. Surveying a number of countries in Asia (including Japan, India, China and Singapore), she observes that these democracies had a few factors in common, including:

A communitarian sense which teaches that the individual is important as part of a group

or society rather than the notion that the individual is the centrepiece of democracy.

A greater acceptance of and respect for authority and hierarchy.

A dominant party that can remain in power for two to three decades or more.

A centralised bureaucracy and a strong state.

(see Chan, 1993: 22-24)

Chan suggests that 'indigenous cultures and folkways are impossible to erase', and this is why transplanted political institutions should not be expected to look or function in the same way as in their place of origin; and, while there are varying degrees of openness and competition, Chan observes that these characteristics are sufficiently similar and significant to warrant 'Asian' democracies being regarded as a different variant, and ventures her belief that this is not a transitory form that would eventually evolve into the Anglo-American version (Chan, 1993: 25).

A few observations can be made here with respect to 'Asian' values and democracy. At the heart of the 'Asian' values debate is the attempt to understand and articulate the values that lie at the centre of a culture, and define a society and its future direction. However, there isn't in Asia the advocacy of a well defined set of values, and nor is there any consensus on these. Where values in Europe are concerned, what constitutes liberal values are elaborated on and supported by the institutional framework undergirding these values. In contrast, 'Asian' values tend to be defined by the elite, usually the political leaders. Hence, the nature of such 
values, and the form(s) of democracy appropriate to these values, are less clear cut. Whatever the case may be, the debate about 'Asian' values reached its peak in the 1990s, and has since died down. However, countries like Singapore have quietly continued to carve out and pursue their version of 'Asian' values and democracy, and the school curriculum and texts have been designed accordingly.

\section{Singapore: History and citizenship education in an 'Asian' democracy}

One way in which the ideals of 'Asian' values and democracy are promoted in Singapore is through the education system. This section will look specifically at the way history is taught, and the implications of this for citizenship education. History is a compulsory subject in school as part of the primary Social Studies syllabus, and as a 'stand alone' subject at the lower secondary level. This paper will use primary Social Studies and lower secondary History texts.

Textbooks in Singapore follow the syllabus set by the Ministry of Education. Until recently, these were all produced by the Curriculum Planning and Development Division of the Ministry. There is now an opening up for other textbook publishers to offer alternatives, but the choice is limited. As cultural artefacts, textbooks in Singapore have a different status from those in Western Europe. The latter can be described as the 'products of contestation and consensus' and, as such, can be deemed to be 'public representations of national collectivities and identities' (Soysal et al, 2005: 14). In Singapore, however, textbooks and their content and pedagogy, reflect the ideology of the political leaders to a high degree, with the curriculum and texts being highly responsive to important political speeches and opinions. With an official syllabus, there are limits anyway in terms of how far publishers can depart from set guidelines. In addition, the general political atmosphere in the country - with limitations on freedom of the media and of expression, for instance ensures a high degree of conformity.

History textbooks in Singapore

In this section, I shall be looking specifically at:

- the historical narrative and, particularly, the interpretation of historical events;

- the 'messages' that are put across in the text; and

- the way in which thinking skills and the idea of history are handled.

I shall relate the above to the values and the form of democracy that are being promoted and, by comparing this approach with those used in other, liberal countries, elucidate the differences in the values and forms of democracy that underlie the different approaches.

History is compulsory as part of the Social Studies curriculum in primary school (6plus to 11plus), with Geography being the other component. The following textbooks were used for analysis:

1. Social Studies 1: Interacting with Our World: Our School

2. Social Studies 2: Interacting with our World: Our Neighbourhood

3. Social Studies 3: Discovering Our World: Our Heritage

4. Social Studies 4A: Discovering our World: Our Physical Environment

5. Social Studies 4B: The Dark Years

6. Social Studies 5A EM 1/2: Birth of a Nation

7. Social Studies 5B EM 1/2: Discovering Our World: Needs of a New Nation

8. Social Studies 6A: Discovering Our World: Our Progress as a Nation

9. Social Studies 6B EM 1/2: Discovering Our World: Our Links with Other Countries 
In secondary school, History is compulsory at lower secondary level (11plus and 12plus). There is a choice of two textbooks, both of which have been approved by the Ministry of Education for use in schools. Both were used for analysis:

1. Insight: History 1: A Learning Journey into the Ancient World of India, Southeast Asia and China (N. Kelly and J. Shuter)

2. The Living Past: History of Ancient India, China and Southeast Asia (A. Major)

Analysis: primary Social Studies textbooks

The upper primary Social Studies texts that deal with history topics bear such titles as 'The Dark Years', 'Birth of a Nation', and 'Our Progress as a Nation'. The very titles, as Goh and Gopinathan have observed, are emotive (Goh and Gopinathan, 2005: 219), and clearly intended to reinforce the National Education and other messages which come across very clearly in the text. In dealing with the Japanese occupation, for instance, there is a clear sense that the British soldiers did not defend Singapore effectively, that the Japanese occupiers were cruel, and that it would be better for Singaporeans to govern their own country. At the same time, the electoral practice of voting for a group of candidates - which is peculiar to Singapore, and which some critics regard as being dubious in democratic terms - is described without question along with other, more generally accepted democratic practices (CPDD, 2000: 16). Similarly, in describing Members of Parliament (MPs) Meet-The-People sessions, children are told these are opportunities for Singaporeans to share their concerns with their MPs, who 'try their best to help'. The view presented of the relationship of the voter to the MP is not so much one in which the latter is answerable to the former, but rather one in which the voter is placed in the position of a petitioner (see Chan, 1989). Again, this practice is presented as the accepted and unquestioned norm. The effect is that children are being socialised into accepting a view of history regarded by the political leaders as being necessary for the country' survival, electoral practices that are distinctive to Singapore, as well as a rather passive conception of citizenship.

In dealing with Singapore's membership of supranational organisations such as ASEAN, the Commonwealth of Nations, and the United Nations (UN), the emphasis is on the dependence of Singapore on other countries for trade, the need to maintain good relations with other countries, and the work of such organisations in making the world a more peaceful place (CPDD, 2000: 72-73; CPDD, 2001d: 68ff). ASEAN is described as an organisation contributing to the peace, growth and stability of the region, to the strengthening of diplomatic ties, and to the promotion of trade among member countries. As was seen, there isn't in ASEAN a set of agreed values. Where the UN is concerned, children are given factual information, e.g. when it was formed, the number of many member countries, and the languages used. There is no reference to the values upheld by the UN or its Declarations. There is no sense - unlike the situation in European countries vis-à-vis the European Union, for instance - of the importance of the sets of values espoused by those organisations, or the need or attempt to incorporate those values within the law or curriculum of the country.

There is, as with the rest of the curriculum in Singapore, the stated aim in the Social Studies syllabus to teach, not just knowledge and values, but also critical and creative thinking skills to enable children to participate in the knowledge economy. These include:

Brainstorming creative solutions to problems

Considering the advantages and disadvantages of a problem

Identifying a problem, and providing innovative solutions to problems

Taking different perspectives, generating new ways of viewing a situation and

developing arguments

Exploring ideas beyond what is given

(see Ministry of Education, 2005a and 2005b) 
In each chapter, children are given the opportunity to exercise one or more of these skills. However, the questions children are asked sometimes read as if these are intended to reinforce the interpretation of the text rather than to foster critical and creative thought, e.g.:

'What are some ways in which we can show our loyalty to Singapore?'

'What do you think are some ways in which Singapore can be weakened?'

(CPDD, 2001b: 79-80)

In addition, the use of 'us', 'we' and 'our' suggests that there is neither attempt nor pretence at neutrality or objectivity.

Hence, there is what Kho refers to as a 'single dominant perspective' that is presented in Social Studies texts (Kho, 2005: 9), and this is a perspective that is sometimes unquestioning as well. While some may argue that a clear and singular narrative is necessary in a young country to foster a sense of national purpose, identity and destiny, such an approach history must work against critical thinking. Hence, although Sim and Print rightly note that 'the emphasis on thinking in social studies per se is a significant departure from past citizenship education programmes' (Sim and Print, 2005a: 10), Koh's view is that this 'does not accommodate the critique of political economy and society (Koh, 2003, cited in Sim and Print, 2005a: 11).

Analysis: lower secondary History textbooks

Intended for lower secondary one and two pupils, the History texts - like those for Social Studies - also teach thinking skills, e.g.:

- $\quad$ analysis
- $\quad$ decision making and elaborating
classifying source materials
recognising bias in sources
making deductions and inferences
(see, for example, Kelly and Shuter, 2006: 3; Major, 2006: 21)

An additional element is that both the History textbooks start with the subject of history itself, and covers topics such as:

- $\quad$ what is meant by 'history'
how history is carried out - primary and secondary history, the nature of evidence
bias in historical writing
the difference between fact and opinion
(see Kelly and Shuter, 2006: 2ff; Major, 2006: 4ff)

All this is to the good, and goes some way to help children develop the tools needed to exercise critical and independent judgment about historical and other issues.

However, the situation is rather different where the content is concerned. The texts follow the Ministry of Education syllabus, and cover the ancient history of India, China and Southeast Asia. And there are areas in which the ruling People's Action Party's 'spin' on history can clearly be seen. In discussing the topic of government in the ancient civilisations, for instance, there is the repeated emphasis on the importance of a 'strong, stable government' (Kelly and Shuter, 2006: 38, 43, 50, 52). Given the political leaders' stance on this type of government, it is not difficult to make the link between their view and that presented in the textbooks. Similarly, where the text deals with forms of government and social systems, democracy and meritocracy are held up as the most desirable among the alternatives; Singapore is clearly identified as a democracy, and the idea that it could possibly be an autocracy dismissed (Kelly and Shuter, 2006: 60).

Where it comes to systems of belief, the major schools like Hinduism, Buddhism, Islam, Confucianism, Legalism, Taoism and Christianity are all covered. However, given that former Prime Minister Lee Kuan 
Yew has use the terms 'Asian' values' and 'Confucian values' interchangeably, it is perhaps significant that there is also reference to the moral, social and political teachings of Confucius. The Kelly and Shuter text state that, according to Confucius, people should learn from their elders and the past, that education and learning were important, and that he taught the idea that the ruler had to look after his people before they had a duty to obey him (Kelly and Shuter, 2006: 94). This last concept, though not named in the text, is usually spoken of as the mandate of heaven, and the Major text does make direct reference to this (Major, 2006: 88, 57). There is a good fit between all this and Lee Kuan Yew's version of 'Asian' values and democracy. There is a similarly good fit between the text and the ruling PAP's claim to have a mandate to rule - though, in their case, the mandate is deemed to come, not from heaven, but from the people through elections (Ibrahim, 2006; The Straits Times, 2006a).

\section{Discussion}

In modern nation states, the teaching of history carries 'the burden of identity-building of citizens' (Soysal and Schissler, 2005: 2). In EU member states in recent years, there has been a 'Europeanisation' of textbooks. In French and German History textbooks, for instance, nationalist content and the nationalising mission of education has increasingly been replaced with 'a pronounced European dimension', as well as 'an increasing emphasis... on wider European ideals and civic traditions (broadly defined as democratic principles, social justice, and human rights)' (Soysal et al, 2005: 22).

In the case of Singapore, however, there isn't the sense that the political leaders or the curriculum developers are referring or conforming to the wider Asian or even the relatively smaller ASEAN community, where values and democracy are concerned. So, although history and citizenship education is justified in terms of an 'Asian' democracy, it has been seen that the conception of such a democracy can be local in nature, and specifically tailored to a Singaporean viewpoint or, even, that of the political leaders. Commentators have expressed concern, for instance, about the unquestioning teaching of electoral and other practices unique to Singapore, as well as fears that, not only might these practices serve the interests of the ruling party, but also children are being socialised into accepting these without question (see, for instance, Sim and Print, 2005a: 9; Tan and Chew, 2004: 601). In addition, the fact that there are no wider and widely accepted version 'Asian' values and democracy, to which the Singapore authorities could or should refer, compounds the problem. The use of the term 'Asian' values and democracy' implies such a frame of reference which, in turn, appears to confer a degree of validity on the form of values and democracy that claims to be so derived; but, unlike the European situation where there is such an institutional context, the lack of consensus and supporting institutional framework means not only divergence, but a temptation towards, and a masking of, national and, arguably, party political interests and concerns.

Also, as was seen, there are significant differences in the way controversial issues such as war are dealt with in Singapore and in a Western liberal country like England. Indeed, issues considered controversial in other countries may not be regarded as such by the political leaders in Singapore. In addition, the handling of such issues reflects fundamental differences in the way children are perceived, and the way the aims of education are conceived. In dealing with the Second World War, for instance, care is taken in England to avoid the brutalisation of children's sensibilities so as to develop the tolerant citizen who sees others as persons, and invests them with value and rights. Delaying the handling of the political issues related to war to the secondary level, when older children can exercise their own critical judgement, is also important with respect to the aim of developing children's autonomy that is part of the liberal tradition.

In Singapore, there is no reticence in dealing with brutal subject matters where young children are concerned, and neither is the developing of and respect for their autonomy an overriding concern. As Kho observes, children in primary school are exposed to often graphic accounts of the Second World War and the sufferings of the people who lived through the Japanese Occupation (Kho, 2005: 2). Hence, topics of war and politics, 
the types of government and electoral practices that are desirable, and the kind of attitudes the children should have with regard to Singapore and fellow citizens, are all dealt with overtly at primary level, and unambiguously couched in the official, approved narrative. It is the nurturing of a sense of identity with, and loyalty and attachment to the country, so as to ensure its survival, that is deemed paramount. This is in keeping with the guidelines of the Desired Outcomes of Education (Ministry of Education, 2004b): primary school children are to be taught to 'love Singapore', secondary children to 'know Singapore', and junior college ('A' level) students to 'lead Singapore'. The fact that children are expected to learn to 'love Singapore' before they develop the intellectual ability needed to 'know Singapore' suggests that uncritical patriotic education is what is intended: what is important is that schoolchildren must learn to love and be committed to the country. Liberals will regard this as being uncomfortably close to indoctrination. There is also the question as to whether it is possible for children to develop critical and creative thinking without a concerted effort also to develop and respect their autonomy.

Admittedly, and in addition to thinking skills, there is the attempt to foster a critical awareness of the subject of history. Since 2002, there has been the inclusion in the History texts of topics concerned with the nature and methodology of history, and children are taught about sources of history, and biases in interpretation. There is also, scattered throughout the texts, encouragement to students to exercise critical thinking skills. All this is in itself a vast improvement from what there was - or, rather, wasn't - in the past, and is to be commended. If children have the tools to view interpretations of history critically, then they are less likely to accept what they are told completely unquestioningly.

However, a number of criticisms can be made with regard to the approach to history education in terms of preparing children for citizenship. First, the children would have been taught uncritical patriotism in primary school, and it would be difficult for them to break out of that mould subsequently. Second, the general political atmosphere is such that there are limits to the range of criticisms that may be made concerning government and society, as well as the forms these may take, and children would have been socialised in schools to accept these 'boundaries'. Third, the main driving force for the encouragement of critical and creative thinking is of an economic nature: it is the result of the need to produce Singaporeans who will be able to compete effectively in the knowledge economy and in the face of globalisation. Even if children were able to develop these skills given the constraints described, the likelihood is that they will mainly be encouraged to exercise such skills in these practical areas, or within the confines of the official narrative. There is therefore the question as to how far this can constitute critical thinking at all. Finally, liberals will feel concerned about the implied elitist approach to education. For those who go no further than primary school, they would presumably remain at 'loving' Singapore. The aspect of critical and creative thinking is to be encouraged largely in those who progress to secondary school and, particularly, junior college and beyond. The likelihood is that a small elite group who will be able (and encouraged) to overcome the constraints and develop the capacity to exercise critical judgment, while ability of the majority to do so will remain limited. Overall, therefore, there is therefore an overriding sense that a single, approved narrative, and a set of the values and messages that are deemed important by the political leaders to the survival of Singapore, are being put across in the history texts. This is intentional and unapologetic, but it raises concerns about the degree of political socialisation that is taking place. While the form of values and democracy taught are described as 'Asian', it is argued that children are in fact being socialised into accepting a rather passive conception of citizenship and a notion of democracy that are distinctive to Singapore.

\section{Conclusion}

In Europe, democratisation in Eastern and other European countries takes place against a backdrop of liberal and democratic traditions of thought that have been articulated and developed by philosophers, social 
scientists and politicians over a few centuries. At the same time, there is the fact of the European Union (EU), the Council of Europe and the related institutions. Hence, although Europe is culturally diverse, and increasingly so as the EU enlargement process continues, there is a widespread shared commitment to the values of liberal democracy and human rights, even where these may not always be observed.

It was argued that the situation in Asia is rather different. By examining the interpretation used in history texts in schools, and comparing the different contexts in which European and 'Asian' values are embedded and used, the paper shows that there is indeed a distinctive form of values and democracy that is taught in Singapore. But, while this is referred to as 'Asian', there is in fact a lacuna in terms of the wider values framework and context, and children are in effect being socialised into accepting a rather passive conception of citizenship and a notion of democracy that are arguably distinctive to Singapore. What Asia stands for is far too diverse, and perhaps there is also, on the part of Singapore and its political leaders, an inclination to make 'Asian' values in their own image, as it were.

\section{Acknowledgement}

My thanks to Andy Green, Germ Janmaat, and the two anonymous referees for their comments on an earlier version of this paper, and also to the students of the M.A. (Comparative Education) course whose observations helped me formulate my ideas for this paper.

\section{References}

Adler, S.A. and Sim, J.B-Y. (2005) Social Studies in Singapore: Contradiction and Control, paper presented at the Redesigning Pedagogy: Research, Policy, Practice Conference, 30 May - 1 June 2005, Centre for Research in Pedagogy and Practice, National Institute of Education, Singapore.

ASEAN (Association of South East Asian Nations) (n.d.) Association of South East Asian Nations. Available online at: http://www.aseansec.org/ (accessed 5 Jun 2006).

Barr, Michael (2000) Lee Kuan Yew and the 'Asian Values' Debate, Asian Studies Review, 24(3), 309-334.

Bell, Daniel A. (2006) Beyond Liberal Democracy: Political Thinking for an East Asian Context, Princeton: Oxford University Press.

Carr, E. H. (1961) What is History?, Second Edition, 1990 reprint (Harmondsworth, Penguin Books).

Central Narcotics Bureau web page (2002) Laws against drug abuse. Available online at: http://www.cnb.gov.sg/enforcement/index.asp?page $=9$ (accessed 18 Jul 2006).

Chan Heng Chee (1989) The PAP and the Structuring of the Political System, in: K.S. Sandhu \& P. Wheatley (Eds) Management of Success: The Moulding of Modern Singapore (Singapore, Institute of Southeast Asian Studies), 70-89.

Chan, H. C. (1993) Democracy: Evolution and Implementation: An Asian Perspective, in: R. Bartley, H.C. Chan, S. Huntington \& S. Ogata (Eds) Democracy and Capitalism: Asian and American Perspectives (Singapore, Institute of Southeast Asian Studies), 1-26.

Chew, Joy Oon Ai (1998) Civics and Moral Education in Singapore: lessons for citizenship education?, Journal of Moral Education, 27(4), 505-524.

Chua Lee Hoong (2006) The hurdles will only get higher, The Straits Times Online, 7 May 2006. Available online at: http://www.straitstimes.asial.com.sg/sub/news/story/0,5562,391324,00.html? (accessed 7 May 2006). 
CPDD (Curriculum Planning and Development Division) (1999a) Social Studies 4A: Discovering our World:

Our Physical Environment, Third impression 2004, Singapore: Marshall Cavendish Education.

CPDD (Curriculum Planning and Development Division) (1999b) Social Studies 4B: The Dark Years, Reprint 2002, Singapore: Marshall Cavendish Education.

CPDD (Curriculum Planning and Development Division) (2000) Social Studies 5A EM 1/2: Birth of a Nation, Second impression 2004, Singapore: Marshall Cavendish Education.

CPDD (Curriculum Planning and Development Division) (2001a) Social Studies 3: Discovering Our World: Our Heritage, Second Impression 2004, Singapore: Marshall Cavendish Education.

CPDD (Curriculum Planning and Development Division) (2001b) Social Studies 5B EM 1/2: Discovering Our World: Needs of a New Nation, Third impression 2004, Singapore: Marshall Cavendish Education.

CPDD (Curriculum Planning and Development Division) (2001c) Social Studies 6A: Discovering Our World: Our Progress as a Nation, Second Impression 2004, Singapore: Marshall Cavendish Education. CPDD (Curriculum Planning and Development Division) (2001d) Social Studies 6B EM 1/2: Discovering Our World: Our Links with Other Countries, Third impression 2004, Singapore: Marshall Cavendish Education.

CPDD (Curriculum Planning and Development Division) (2006a) Social Studies 2: Interacting with our World: Our Neighbourhood, Singapore: Marshall Cavendish Education.

CPDD (Curriculum Planning and Development Division) (2006b) Social Studies 1: Interacting with Our World: Our School, Singapore: Marshall Cavendish Education.

EU (European Union) (n.d.) Europa: Gateway to the European Union. Available online at: http://europa.eu/index en.htm (accessed 5 Jun 2006).

Fernandez, Warren (2006) Casting the wise vote, The Straits Times Online, 8 May 2006. Available online at: http:/www.straitstimes.asial.com.sg/sub/review/story/0,5562,391569,00.html? (accessed 8 May 2006).

Glazer, Nathan (1997) Diffusion of Values and the Pacific Rim, in: J. D., Montgomery (Ed) Values in Education: Social Capital Formation in Asia and the Pacific (Hollis, Pacific Basin Research Centre, Soka University of America), 49-69.

Goh, C. B. and Gopinathan, S (2005) History Education and the Construction of National Identity in Singapore, 1945 - 2000, in: E. Vickers \& A. Jones (Eds) History education and national identity in East Asia (New York, Routledge), 203-225.

Han, C. (1997) Education for Citizenship in a Plural Society: with special reference to Singapore, unpublished doctoral thesis, Green College, University of Oxford.

Han, C. (2000) National Education and 'Active Citizenship': Implications for Citizenship and Citizenship Education in Singapore, Asia Pacific Journal of Education, 20(1), 63-72.

Han, C. (2006) Forging a national identity: the role of a common culture, unpublished paper.

Han, C. and Tan, J (2007) 'Asian' values in Chinese textbooks in Singapore, unpublished paper.

Hein, L. \& Selden, M. (1998) Learning Citizenship from the Past: Textbook Nationalism, Global Context and Social Change, Bulletin of Concerned Asian Scholars, 30(3), 3-15.

Hill, Michael (2000) 'Asian' values as reverse Orientalism: Singapore, Asia-Pacific Viewpoint, 41(2), 177190.

Ho Wing Meng (1989) Value Premises Underlying the Transformation of Singapore, in: K. S. Sandhu \& P, Wheatley (Eds) Management of Success: The Moulding of Modern Singapore (Singapore, Institute of Southeast Asian Studies), 671-691.

Ibrahim, Zuraidah (2006) PM gets his strong mandate, The Straits Times Online, 7 May 2006. Available online at: http://www.straitstimes.asia1.com.sg/sub/news/story/0,5562,391336,00.html? (accessed 7 May 2006). 
Kelly, N. and Shuter, J. (2006) Insight: History 1: A Learning Journey into the Ancient World of India, Southeast Asia and China, Singapore: Pearson Longman.

Kessler, C. S (1999) The Abdication of the Intellectuals: Sociology, Anthropology and the Asian Values Debate - Or, What Everybody Needed to Know About 'Asian Values' That Social Scientists Failed to Point Out, Sojourn, 14(2), 295-312.

Kho, E.M. (2005) 'Demonizing the Japanese Occupation': Exploring Ideological Discourses in Singapore History and Social Studies Textbooks, paper presented at the International Conference, The Japanese Occupation: Sixty Years after the End of the Asia-Pacific War, Singapore, September 2005.

Khoo Boo Teik (1999) The Value(s) of a Miracle: Malaysian and Singaporean Elite Construction of Asia, Asian Studies Review, 23(2), 181-192.

Koh, Aaron (2002) Towards a critical pedagogy: creating 'thinking schools' in Singapore, Journal of Curriculum Studies, 34(3), 255-264.

Koh, Aaron (2005) Imagining the Singapore 'Nation' and 'Identity': The role of the media and National Education, Asia Pacific Journal of Education, 25(1), 75-91.

Maier, Robert (2005) Learning about Europe and the World: Schools, Teachers, and Textbooks in Russia after 1991, in: H. Schissler \& N. Soysal (Eds) The Nation, Europe, and the World: Textbooks and Curricula in Transition (New York, Berghahn Books), 138-162.

Major, Andrew (2006) The Living Past: History of Ancient India, China and Southeast Asia, second edition, (Singapore, Marshall Cavendish Education).

Manan, W. A. (1999) A Nation in Distress: Human Rights, Authoritarianism, and Asian Values in Malaysia, Sojourn, 14(1), 359-381.

MOE (Ministry of Education) (2004a) National Education: Six Messages. Available online at: http://www.moe.gov.sg/ne/aboutne/sixmsgs.htm (accessed 19 Jan 2007).

MOE (Ministry of Education) (2004b) Desired Outcomes of Singapore. Available online at: http://www.moe.gov.sg/corporate/desired outcomes4.htm (accessed 19 Jul 2006).

MOE (Ministry of Education) (2005a) Social Studies Syllabus, Singapore: Curriculum and Planning Development Division. Available online at: http://www.moe.gov.sg/cpdd/doc/SocialStudies_Pri(2006).pdf(accessed 25 May 2006).

MOE (Ministry of Education) (2005b) History Syllabus: Lower Secondary, Singapore: Curriculum Planning and Development Division. Available online at: http://www.moe.gov.sg/cpdd/doc/History_Lower_Sec_(2006).pdf (accessed 25 May 2006).

Montgomery, J. D. (1997) Are Asian Values Different?, in: J. D. Montgomery (Ed) Values in Education: Social Capital Formation in Asia and the Pacific (Hollis, Pacific Basin Research Centre, Soka University of America), 29-47.

Rossi, Tony and Ryan, Mary (2006) National Education as 'Civics' Literacy in a Globalized World: The challenges facing education in Singapore, Discourse, 27(2), 161-174.

Sim, J.B-Y. and Print, M. (2005a) Citizenship Education and Social Studies in Singapore: A National Agenda, International Journal of Citizenship and Teacher Education, 1(1), 58-73.

Sim, J.B-Y. and Print (2005b) Social Studies Teachers' Understandings of Citizenship and Citizenship Education, paper presented at the Redesigning Pedagogy: Research, Policy, Practice Conference, 30 May - 1 June 2005, Centre for Research in Pedagogy and Practice, National Institute of Education, Singapore.

Soysal, Y. N., Bertilotti, T. and Mannitz, S. (2005) Projections of Identity in French and German History and Civics Textbooks, in: H. Schissler \& N. Soysal (Eds) The Nation, Europe, and the World: Textbooks and Curricula in Transition (New York, Berghahn Books), 14-34. 
Soysal, Y. N. and Schissler, H. (2005) Introduction: Teaching beyond the National Narrative, in: H. Schissler \& N. Soysal (Eds) The Nation, Europe, and the World: Textbooks and Curricula in Transition (New York, Berghahn Books), 1-9.

Tan, Jason (1997) The rise and fall of religious knowledge in Singapore secondary schools, Journal of Curriculum Studies, 29(5), 603-624.

Tan Tai Wei (1994) Moral education in Singapore: a critical appraisal, Journal of Moral Education, 23(1), 6173.

Tan, T.W. and Chew L.C. (2004) Moral and citizenship education as statecraft in Singapore: a curriculum critique, Journal of Moral Education, 33(4), 597-606.

The Straits Times Online (2006a) Election results a strong mandate for PAP: MM, 7 May 2006. Available online at: http://www.straitstimes.asia1.com.sg/sub/latest/story/0,5562,391418,00.html? (accessed 7 May 2006).

The Straits Times Online (2006b) '66.6\% win surpasses PM's own estimate', The Straits Times, 8 May 2006. Available online at: http:/www.straitstimes.asia1.com.sg/sub/singapore/story/0,5562,391518,00.html? (accessed 8 May 2006).

The Straits Times Online (2006c) 'They vote opposition but want PAP in power', The Straits Times, 13 May 2006. Available online at: http://www.straitstimes.asia1.com.sg/sub/review/story/0,5562,3927421147557540,00.html? (accessed 15 May 2006).

The Straits Times Online (2006d) 'Govt promises review of new media, 'lighter touch' in next GE', The Straits Times, 31 May $2006 . \quad$ Available online at: http://www.straitstimes.asia1.com.sg/portal/site/STI/menuitem.b0c342bf39ac6a158ace2810a06310a0/? uid=christinehan\&pwd=EVIWnwnoEXIbb3vcoWLcII366IzW3JPRZtPBCO66IzW3JPR\&ssID=33298371 e2412457\&remme callback=1\&vgnextoid=d720758920e39010VgnVCM1000000a35010aRCRD\&vgnex tfmt=vgnartid:472938c43498b010VgnVCM100000430a0a0aRCRD (accessed 31 May 2006).

Wang, C.K.J., Khoo, A., Goh, C.B., Tan, S. and Gopinathan, S. (2006) Patriotism and National Education: PercEptions of trainee teachers in Singapore, Asia Pacific Journal of Education, 26(1), 51-64.

Wee, C. J. W-L (1999) 'Asian Values', Singapore and the Third Way: Re-working Individualism and Collectivism, Sojourn, 14(2), 332-358.

World Conference on Human Rights (1993) Report of the Regional Meeting for Asia of the World Conference on Human Rights, Bangkok (The Bangkok Declaration), 29 March - 3 April 1993. Available online at: http://www.unhchr.ch/html/menu5/wcbangk.htm (accessed 18 July 2006).

$\mathrm{Xu}$, Xiaoge (2005) Demystifying Asian Values in Journalism (Singapore, Marshall Cavendish Academic).

Zakaria, Fareed (1994) Culture is Destiny: A Conversation with Lee Kuan Yew, Foreign Affairs, 73(2), 109126. 